\title{
Empowerment of Sto.Yohanes Maria Vianey Catholic Church Youth - Naibonat of East Kupang, East Nusa Tenggara as A Supervision of Tuberculosis Ingestion
}

\author{
Novian A. Yudhaswara ${ }^{1, a)}$, M. Ibraar Ayatullah'2, \\ Novelia G So'o', Irwan Budiana ${ }^{3}$, and Norma T Kambuno' \\ 1,3,5 Diploma III Study Program in Medical Laboratory Technology, Health Polytechnic, Ministry of Health \\ Kupang, Indonesia \\ ${ }^{2}$ Diploma III Dental Health Study Program, Health Polytechnic of the Ministry of Health Kupang, Indonesia \\ ${ }^{3}$ Diploma III Nursing Study Program, Health Polytechnic of the Ministry of Health Kupang, Indonesia \\ a)Corresponding Author: novianagni@yahoo.com
}

\begin{abstract}
Tuberculosis (TB) is an infectious disease that causes death, and is the third leading cause of death in Indonesia. The increase in cases of tuberculosis infection is still a major health problem in Naibonat Village, Kupang Regency, East Nusa Tenggara Province. Treatment failure, among others, was caused by patient non-compliance in ingesting drugs. It is hoped that the presence of supervisors to swallow drugs for TB patients is expected to help reduce TB infection cases. In Indonesian, a person who supervisors to swallow drugs is called "PMO" or "Pengawas menelan obat (PMO)". Church Youth is an educated / educated group that is expected to have the ability to function as PMO. The purpose of this activity is to carry out PMO training for STO. Yohanes Maria Vianey Naibonat church youth through the method of lectures, discussions and microscopic training. The level of knowledge was measured using a questionnaire in the pre-test and post-test training. Youth who have been trained will be directed to become PMO's for their families and closest neighbors who suffer from TB as well as agents of change in changing healthy behavior to prevent TB infection. The results of the activity showed a change in the level of knowledge before and after training from $72 \%$ enough category to be good $89 \%$. It was concluded that empowering church youth as PMO is an effort to suppress the increase in TB cases. The provision of PMO training can increase level of knowledge about TB so that regular and scheduled training will increase the ability and understanding of the role of PMO in reducing the incidence of TB in the community.
\end{abstract}

Key words: Church Youth, PMO, Tuberculosis, Health Training

\section{INTRODUCTION}

Tuberculosis (TB) is an infectious disease caused by the bacterium Mycobacterium tuberculosis which causes over 10.4 million cases and 1.4 million deaths annually. TB usually attacks the lungs but can also affect other parts of the body (Webb, Kali Vanan, and Biswas 2018)(World Health Organization 2020)(Kementerian Kesehatan RI, 2018)(Bai, 2014). Spread through the air, when a person with the disease coughs, sneezes, talks or spits (Laka 2013). Most human infections are latent and asymptomatic, with about one in ten latent infections eventually progressing to active disease (Aziz, 2018)(Namuwali, 2017). Left untreated, active TB kills between $20 \%$ and $70 \%$ of its victims within ten years depending on severity (Kementrian Kesehatan Republik Indonesia, 2013)(Nugroho, 2011)(Ananthakrishnan et al., 2019).

TB is also the leading cause of death from infectious diseases in the Asia-Pacific. In 2018, there were 10 million incidents (new and relapsing) of TB cases worldwide, 1.2 million deaths among HIV-negative people globally. More than $40 \%$ of new cases and nearly half of the deaths are estimated in India, Indonesia and Pakistan. The five countries in the world that collectively account for $56 \%$ of the estimated global TB cases in 2018 are in the Asia Pacific region: India (2.69 million), China (0.86 million), Indonesia (0.84 million), Philippines (0.59 million) and Pakistan (0.56 million) (Kementrian Kesehatan Republik Indonesia, 2013) (Kemenkes, R. I., 2018)(World Health Organization 2020)(Machmud, Medison, and Yani 2020). 
The World Health Organization reports that Indonesia ranks third with case TB the highest in this world (Respati and Sufrie 2014). Meanwhile, the first and second positions are India and China. If you look at WHO data for 2019, the estimated number of TB cases in Indonesia is 845,000 people (Parwati et al. 2020)(Noerfitri et al. 2019). This number increased from the previous 843,000 people. This puts Indonesia as one of the countries that accounts for $60 \%$ of all world TB cases. The number of TB cases found in 2018 was around 566,000 cases. This figure increased from the TB disease data recorded in 2017, which was in the range of 446,000 cases(World Health Organization 2020)(Sharma et al. 2019).

BPJS data for 2020, the population of East Nusa Tenggara is 5,541. 394 jiwa. The 2018 Basic Health Research data shows that the number of TB cases in East Nusa Tenggara Province is 12,091 cases with the highest distribution of cases in TTS District with 623 cases and Kupang City with 1,303 cases, and cases in the district Kupang as many as 610 cases ( Kemenkes, R. I., 2018). Naibonat is a village in East Kupang District, Kupang Regency as the location for community service activities with a total of 50 TB cases. This village has a population of 1553 people with 347 families (Kementerian Kesehatan RI 2018).

TB disease prevention programs throughout Indonesia are still experiencing many obstacles and are still far from being expected. One of the main causes is the high patient adherence to treatment (Machmud, at al., 2020)(Kambuno et al. 2019). Therefore, the issue of patient adherence in completing the treatment program is the most important priority (Dhewi, et al., 2013). The inability of the patient to complete the self-administered regimen, will lead to treatment failure, possible disease relapse, drug resistance and will continue to transmit infection (Gero et al. 2017)(Purwanta 2005). Each potential pulmonary TB patient can transmit the disease to 15 new patients per year. Patient compliance in completing the treatment program in active TB cases is the most important priority for controlling the program (Wulandari 2015)(Paru 2011). An increase in the percentage of patients who seek regular treatment (adhere) will have a positive impact, namely reducing transmission rates, reducing recurrence, inhibiting germ growth, reducing germs resistance to drugs, and reducing patient disability. Eventually the number of TB patients will decrease (Risnawati 2016)(Anthony, 2020).

TB treatment will cure most patients without triggering the emergence of drug resistant (resistant) germs. To achieve this, it is very important to ensure that the patient swallows all the drugs given as directed by direct supervision by a PMO (Drug Drinking Supervisor, or often called Drug Swallowing Supervisor) in order to prevent drug resistance (resistance) (Maulidya, et al., 2017)(Sitorus, et. al., 2017).

Based on the description in the introduction, the problem raised in community service activities is how to improve the ability of church youths to become supervisors to take medicine (PMO) in Naibonat village. The aim is to conduct training for church youth / Catholic youth of the STO. Yohanes Maria Vianey Naibonat church.

\section{METHOD}

The population of this research was all church youth / Catholic youth STO. Yohanes Maria Vianey Naibonat. The sample of this study was 28 church youths who were willing to become respondents / trainees. Measurement of knowledge using a questionnaire that had been validated and carried out twice, namely pre-test before carrying out training and post-test after training. The training model was lectures, discussion in small groups and direct practice of microscopic observation of Mycobacterium tuberculosis. Data Analysis: Basic data were summarized descriptively, tabulated in tables and given an explanation. The results of measuring knowledge were grouped into 3 categories, namely: Good (76\%-100\%), Enough (56\% - $75 \%)$, and Less (0-55\%).

\section{RESULTS}

Training is carried out The week following the Mass on Sunday, November 1, 2020 in the church building STO. Yohanes Maria Vianey Naibonat, Kupang Regency, East Nusa Tenggara. 
The implementation of the activity is a follow-up to the previous year's community service, the community service team asked for permission and approval to carry out activities in partner areas, namely the head / priest of the STO.Yohanes Maria Vianey Naibonat church. The training was attended by 28 respondents. The characteristics of the respondents are shown in Table 1 below:

Table 1. Characteristics of respondents / participants in PMO training

\begin{tabular}{|c|c|c|c|}
\hline No. & Characteristics & $\mathbf{n}$ & $\%$ \\
\hline \multirow[t]{3}{*}{1} & Gender & & \\
\hline & Male & 12 & 42.9 \\
\hline & Female & 16 & 57.1 \\
\hline \multirow[t]{3}{*}{2} & Age & & \\
\hline & $10-19$ years & 8 & 28.6 \\
\hline & $20-29$ years & 20 & 71.4 \\
\hline \multirow[t]{5}{*}{3} & Education & & \\
\hline & Elementary & 0 & 0 \\
\hline & Junior High & 4 & 14.3 \\
\hline & High school & 12 & 42.9 \\
\hline & University & 12 & 42.9 \\
\hline \multirow[t]{4}{*}{4} & Have family members of TB patients & & \\
\hline & Ye & 12 & 42.9 \\
\hline & $s$ & 16 & 57.1 \\
\hline & No & & \\
\hline \multirow[t]{4}{*}{5} & Have had TB & & \\
\hline & $Y e$ & 8 & 28.6 \\
\hline & $s$ & 20 & 71.4 \\
\hline & No & & \\
\hline \multirow[t]{3}{*}{6} & Never heard of PMO & & \\
\hline & Yes & 14 & 50 \\
\hline & No & 14 & 50 \\
\hline \multirow[t]{3}{*}{7} & Know the function of PMO & & \\
\hline & Yes & 14 & 50 \\
\hline & No & 14 & 50 \\
\hline
\end{tabular}

Table 1 shows that the participants were dominated by women, namely 16 people $(57.1 \%)$, with the largest age being 20-29 years (71.4\%). Most of the participants had high school education (42.9\%) and University (42.9. \%), as many as 16 people (57.1\%) admitted to having TB companion members, as many as 20 people $(71.4 \%)$ participants admitted to having suffered from TB, as many as 14 people (50\%) claimed to have heard about PMO and also knew the function of PMO .

The training methods provided were lectures, discussions in small group discussions and also the practice of microscopic observation of BTA (Acid Resistant Basil) bacteria with a positive range of 1 , positive 2 and also positive 3 . The level of knowledge of participants about TB disease was measured using a questionnaire conducted on the beginning of training and after training. Table 2 below shows the results of the summary of respondents' answers for each question answer. 
Table 2. Summary of respondents' answers

No.

The number of respondents answered

Question incorrectly

\begin{tabular}{|c|c|c|c|c|c|}
\hline & & \multicolumn{2}{|c|}{ Pre Test } & \multicolumn{2}{|c|}{ Post Test } \\
\hline & & Incorrect & Correct & Incorrect & Correct \\
\hline 1 & What is TB disease & 18 & 10 & 0 & 28 \\
\hline 2 & Causes of pulmonary tuberculosis & 15 & 13 & 0 & 28 \\
\hline 3 & $\begin{array}{l}\text { How signs / symptoms TB } \\
\text { disease }\end{array}$ & 12 & 16 & 0 & 28 \\
\hline 4 & $\begin{array}{l}\text { The cause of TB disease can be } \\
\text { transmitted to other family } \\
\text { members }\end{array}$ & & & & \\
\hline & & 0 & 8 & 0 & 28 \\
\hline 5 & $\begin{array}{l}\text { The purpose of holding the PMO } \\
\text { / Drug Administration training }\end{array}$ & 19 & 9 & 9 & 19 \\
\hline 6 & $\begin{array}{l}\text { The first action if a family } \\
\text { member has TB }\end{array}$ & 12 & 16 & 4 & 24 \\
\hline 7 & Is TB curable & 9 & 19 & 0 & 28 \\
\hline 8 & The best way to prevent TB & 14 & 14 & 0 & 28 \\
\hline 9 & $\begin{array}{l}\text { What is the importance of dental } \\
\text { health in TB sufferers }\end{array}$ & 16 & 12 & 6 & 22 \\
\hline 10 & Mode of transmission of TB & 2 & 26 & 0 & 28 \\
\hline 11 & $\begin{array}{l}\text { The best way to prevent TB } \\
\text { transmission to other people }\end{array}$ & 14 & 14 & 0 & 28 \\
\hline 12 & $\begin{array}{l}\text { How to prevent TB disease } \\
\text { transmission through the floor }\end{array}$ & 11 & 17 & 0 & 28 \\
\hline 13 & $\begin{array}{l}\text { What is the function of home } \\
\text { ventilation }\end{array}$ & 10 & 18 & 0 & 28 \\
\hline 14 & $\begin{array}{l}\text { What is the area of good } \\
\text { ventilation }\end{array}$ & 13 & 15 & 0 & 28 \\
\hline 15 & $\begin{array}{l}\text { What are the conditions for theair } \\
\text { that enters the room of the } \\
\text { house }\end{array}$ & 22 & 6 & 0 & 28 \\
\hline
\end{tabular}


The benefits of morning sunlight for the room of the house

9

How is the natural lighting of the room that meets the

requirements

18

19

20
TB disease can be prevented by immunization

How is the relationship between TB treatment and nutrition

How to cure TB disease
10

18

7

11

14

17
14

11
5

23

0

28

0

28

25

From the 28 youths who took the pre test at the beginning of the training, it was shown that $72 \%$ of them were in the sufficient category. Training comes withusing the Handbook of Church Youth as PMO written by the community service team. Participants were given an explanation and understanding of the dangers of TB disease, its handling and prevention.Participants are taught the method of TB disease transmission and the importance of the community to be especially vigilant for families who already have members with a history of TB or are currently taking treatmen

\section{DISCUSSION}

Based on the results of the analysis of the participants' answers in the pre-test, the most error answers were found in the question of how the air requirements enter the house $(78.6 \%$ of participants answered incorrectly) Most of them chose the answer that the important thing was not smelly and not stuffy and the important thing was that air could enter. On the question, what was the purpose of holding PMO training (67.9\% answered wrong), most respondents chose the answer to justify (determine someone) with TB. The next question is what is meant by pulmonary TB (64.3\% of respondents answered incorrectly), most of them chose the answer to coughing due to smoking and coughing with an itchy throat. Furthermore, on the question whether how to cure TB disease (60.7\% of participants answered incorrectly),

In the final results of the post-test, by distributing the same questionnaire, the results of the increase in the level of knowledge were $89 \%$ in the good category. The significant increase in post-test results shows the success of training and counseling results. The results of the posttest answer analysis showed that there were 6 questions that were still answered incorrectly by the participants. It was found that there were still 9 people $(32.1 \%$ of participants answered incorrectly) on the question about the objectives of conducting PMO training. Likewise, on the question of the importance of dental health in TB sufferers, 6 people $(21.4 \%$ of participants answered incorrectly). There were still 5 people (17.9\%) who answered incorrectly on the question of how natural lighting in the room meets the requirements and how the relationship between TB treatment and nutrition.

Participants are also provided with an understanding of side effects in the form of nausea, vomiting, red urine and stoolin the treatment process that often becomes so that the patient does not stop the treatment. On the same occasion, participants were also taught about MDRTB cases, namely the type of AFB germ that has been resistant to the first level of OAT treatment.(Webb, Kali Vanan, and Biswas 2018). In addition, participants were also given the opportunity to see firsthand through a microspope the forms of positive BTA bacteria and negative examination results and also explainedThe method of examining sputum samples using 
ZN staining is used to identify positive smear by taking the sputum specimen in this examination is done by means of SPS (Time, Morning and Time)(Kambuno et al. 2019).

At the end of the training session, counseling was given on dental health and distribution of toothbrushes and toothpaste, to educate participants about the dangers of exchanging personal hygiene kits in one house. Where exchanging toothbrushes and other equipment will be a source of transmission of TB and other infectious diseases.

PMO is someone who is trusted to supervise and monitor TB sufferers in taking their medication regularly and thoroughly (Kementerian Kesehatan RI 2018)(Wiranata 2019). PMO guarantees patient compliance in taking the medicine according to a predetermined schedule and dose. One of the components of DOTS (Directly Observed Treatment Shortcourse) is shortterm OAT treatment with direct supervision. So to ensure regularity of treatment, a PMO is needed (National Guidelines for Combating Tuberculosis, 2010).

To become a PMO, there are several requirements that must be considered, namely PMO is someone who is known, trusted and approved by both health workers and sufferers, besides that it must be respected and respected by the sufferer. A PMO is also someone who lives close to the sufferer, is willing to help sufferers voluntarily, and is willing to be trained and / or get counseling together with sufferers (Murtiwi 2005)(Putri 2015).

The task of a PMO is to supervise TB sufferers to take medication regularly until after treatment, encourage patients to seek regular treatment, remind patients to recheck sputum at predetermined times, and provide counseling to family members of TB sufferers who have suspicious symptoms to immediately go to the puskesmas or other health services (Risnawati 2016)(Purba 2017).

Important information that PMO needs to understand to convey to patients and their families: 1. TB is caused by germs, not a hereditary disease or a curse 2 . TB can be cured with regular treatment 3. Mode of transmission of TB, suspicious symptoms and ways to prevent it. 4 . How to give patient treatment (intensive and advanced stages). 5 . The importance of supervision so that patients seek regular treatment. 6 . The possibility of drug side effects and the need to ask immediately (Sitorus 2016)(Purwanta 2005).

Several previous studies have suggested the important role of PMO in achieving cure for TB patients. Sitorus et al concluded that the role of PMO and family motivation is very important for the successful treatment of pulmonary tuberculosis patients in the Lung Disease Treatment Unit (UP4) Pontianak. Characteristic factors that play a big role in family motivation and PMO are family background factors and for PMO, such as education, socio-economic conditions, employment and income levels and environmental conditions of residence. The role of PMO in TB sufferers is very

important to supervise patients in terms of ingesting drugs, reminding patients to re- check sputum according to a set schedule, encouraging patients to seek treatment regularly until it's finished, advised the patient to continue to swallow the drug regularly until finished. It was found that the role and motivation of PMO for recovered patients was very good compared to patients who relapsed (Sitorus, et al., 2017).

Maulidya et al concluded that patient attitudes and the presence / absence of PMO had a significant relationship with the success of pulmonary TB treatment. Meanwhile, age, education, income, type of treatment and knowledge had no significant relationship with the success of pulmonary TB treatment. Patients with a "good" attitude had 4.3 times the chance of recovery than patients with a "bad" or "good enough" attitude. Patients who had PMO also tended to have a 13.5 times greater chance of recovery than patients who did not have PMO (Maulidya, et al., 2017).

In line with Istiawan et al, concluded that the relationship between the role of PMO by the family and the prevention behavior of TB clients showed a strong relationship $(r=0.656)$ and had a positive pattern. The higher the role of family PMO, the higher the TB client prevention behavior. If what is taken by the family, it is better if first intensively trained on the role of PMO 
and provided with a module book on PMO. It is better if there should still be health workers, especially community nurses to supervise with home visits(Istiawan, et al., 2006)

Treatment failure and lack of discipline for patients with pulmonary tuberculosis are strongly influenced by the role of PMO. PMO is very important to assist sufferers in order to achieve optimal treatment results. The role of PMO in the TB treatment process is to bring TB patients to health workers, remind patients to take medication, and motivate patients. Good knowledge about TB and the education level of a PMO can influence TB sufferers to comply with antituberculosis drugs so that treatment success can be achieved (Putri 2015).

The opposite was expressed by Murtiwi et al. Where patients thought there was no need for PMO because the presence of PMO had so far been ineffective. This shows that pulmonary TB patients have the potential to be empowered by facilitating the formation of a TB patient group or self-help group (ENT).The presence of PMO on treatment compliance of pulmonary TB patients is not effective, this is shown by the data that $66.6 \%$ of patients were never reminded to take medication, $98.5 \%$ of patients were not monitored while ingesting drugs so that patients thought there was no need for PMO. The results of this study also show that patients have the potential to be empowered. Therefore, these findings prove the importance of community empowerment which can be initiated by facilitating the formation of TB patient groups or selfhelp groups (Murtiwi 2005).

The role of the family towards pulmonary tuberculosis patients in Kawedanan Pedan was mostly in the good category (52.3\%) researched by Risnawati et al. Most of the patients with pulmonary tuberculosis in Kawedanan Pedan were in the adherent category (56.8\%). There is a relationship between the role of the family and adherence to taking medication in patients with pulmonary tuberculosis with the result of $p$-value

$=0.000$ with the Kendall Tau statistical test (Risnawati 2016).

The results of the study by Paru et al. Concluded that the factors behind the drop out of TB treatment included the length of treatment that went through the intensive stage so that the symptoms disappeared and the patient felt cured, treatment funding was not free, the patient did not know about the treatment stages, the absence of PMO, the difficulty of transportation. towards BP4, the side effects of drugs, ignorance of complications of the disease(Nugroho, 2011).

Wulandari et al reported that non-compliance with pulmonary tuberculosis patients was still found to take medication. This non-compliance is due to behavioral (Predisposing, Enabling and Reinforcing) and non-behavioral factors. They suggest that there must be a way to increase compliance with pulmonary TB sufferers to take medication, among others with policy support from the hospital for the TB DOTS program, regular counseling, ensure the availability of drugs, the existence of PMO, and regular recording and reporting (Wulandari 2015).

The magnitude of the PMO's role in achieving the recovery of TB patients is one of the factors that must be considered in Naibonat village. Puskesmas (health center)in Naibonat noted that there were 15 PMOs but the increase in TB cases was still happening every year. The training we carry out will be one of the solutions to reduce TB cases in Naibonat Village. We hope that the 28 church youths we have trained will give a real role specifically to those who have family members of TB patients.

Our research also concludes the importance of regular and scheduled training for PMOs who are registered at the Puskesmas as a form of refresher and strengthening of their functions and roles as PMOs. We recommend to the head of the Puskesmas and the local government to maximize family members who already have knowledge of PMO.

Healthy behavior and habits in the household need to be maintained, maintained and enhanced by each family member. If healthy living habits have been accustomed from an early age, TB infection can be prevented so that the number of TB cases will decrease

CONCLUSIONS And RECOMMENDATIONS 
Empowering Church Youths as Supervisors for Ingesting Drugs is an effort to suppress the increase in TB cases in Naibonat Village, Kupang Regency, East Nusa Tenggara. Provision of PMO training can increase level of knowledge about TB so that regular and scheduled training will increase the ability and understanding of the role of PMO in reducing the incidence of TB in the community.

\section{ACKNOWLEDGMENTS}

We would like to thank the Director of Health Polytechnic of the Ministry of Health in Kupang, Dr. RH Kristina SKM, M. Kes for the funding support for this community service activity through the budget for DIPA Poltekkes Kupang Ministry of Health Fiscal Year 2020. Thanks to Romo Andi as the person in charge of STO. Yohanes Maria Vianey Naibonat church also addressed Mr. Bony, as the station manager and Mofix as the head of Catholic Youth / Youth

\section{REFERENCES}

Ananthakrishnan, R., Richardson, M. A., van den Hof, S., Rangaswamy, R., Thiagesan, R., Auguesteen, S., \& Kamp, N. (2019). Successfully engaging private providers to improve diagnosis, notification, and treatment of TB and drug-resistant TB: the EQUIP publicprivate model in Chennai, India. Global Health: Science and Practice, 7(1), 41-53.

Anthony, W. (2020). Hubungan PMO (Pengawas Menelan Obat) Dengan Kepatuhan Minum Obat Pada Pasien Tuberkulosis Di Wilayah Kerja Puskesmas Dimong Kabupaten Madiun, Skripsi. Stikes Bhakti Husada Mulia Madiun).

Aziz, K. K. (2018). Hubungan Pemberian ASI Eksklusif Dengan Kejadian Tuberkulosis Paru Pada Anak. Jurnal Info Kesehatan, 16(2), 236-243.

Bai, M. K. S. (2014). Hubungan Tingkat Pendidikan dan Pengetahuan Penderita Tb Paru dengan Perilaku Pembuangan Dahak di Puskesmas Rewarangga Kecamatan Ende Timur Kabupaten Ende. Jurnal Info Kesehatan, 12(1), 551-556.

Gero, S., \& Sayuna, M. (2017). Pencegahan Penyakit Tbc Paru Yang Utama Dimulai Dari Dalam Rumah Penderita. Jurnal Info Kesehatan, 15(1), 120-128.

Istiawan, R., Sahar, J., \& Bachtiar, A. (2006). Hubungan Peran Pengawas Minum Obat oleh Keluarga dengan Petugas Kesehatan Terhadap Pengetahuan, Perilaku Pencegahan, dan Kepatuhan Klien TBC dalam Konteks Keperawatan Komunitas di Kabupaten Wonosobo. Jurnal Keperawatan Soedirman, 1(2), 96-104.

Kambuno, N. T., Senge, Y. H., Djuma, A. W., \& Barung, E. N. (2019). Uji Tuberkulosis Laten Pada Kontak Serumah Pasien BTA Positif Dengan Metode Mantoux Test. Jurnal Info Kesehatan, 17(1), 50-63.

Kementerian Kesehatan RI. (2018). "Info Data Dan Informasi Tuberkulosis Tahun 2018." : 16.

Kementrian Kesehatan Republik Indonesia. (2013). "Pedoman Nasional Pelayanan Kedokteran Tata Laksana Tuberkulosis." Jakarta: 1-100.

Kemenkes, R. I. (2018). Hasil Utama Laporan Riskesdas 2018. Jakarta: Kementerian Kesehatan Republik Indonesia.

Laka, Y. (2013). Analyses on Factors Affecting Tb Infection in Children Living at the Same House with Tb Patients at Waingapu Public Health Center, East Sumba Regency East Nusa Tenggara Province. Jurnal Info Kesehatan, 11(2), 489-499.

Machmud, R., Medison, I., \& Yani, F. F. (2020). Cultural and Religious Belief Approaches of a Tuberculosis Program for Hard-to-Reach Populations in Mentawai and Solok West Sumatera, Indonesia. Kesmas: Jurnal Kesehatan Masyarakat Nasional (National Public Health Journal), 15(4).

Maulidya, Y. N., Redjeki, E. S., \& Fanani, E. (2017). Faktor yang Mempengaruhi Keberhasilan Pengobatan Tuberkulosis (TB) Paru pada Pasien Pasca Pengobatan di Puskesmas Dinoyo Kota Malang. Preventia: The Indonesian Journal of PublicHealth, 2(1), 44-57.

Murtiwi, M. (2006). Keberadaan Pengawas Minum Obat (PMO) Pasien Tuberkulosis Paru di Indonesia. Jurnal Keperawatan Indonesia, 10(1), 11-15. 
Namuwali, D. (2017). Pengaruh Teknik Relaksasi Nafas Dalam Terhadap Kontrol Emosi Pada Penderita TB Paru Di Balai Kesehatan Paru Masyarakat (BKPM) Magelang. Jurnal Info Kesehatan, 15(1), 146-165.

Noerfitri, N., Sutiawan, R., Wahyono, T. Y. M., \& Hartono, P. A. (2019). Influence of Decentralization and Type of Patient on Loss to Follow-up among Multidrug- Resistant Tuberculosis Patients in Indonesia from 2014 to 2015. Kesmas: National Public Health Journal, 13(3), 105-111.

Nugroho, R. A. (2011). Studi kualitatif faktor yang melatarbelakangi drop out pengobatan tuberkulosis paru. KEMAS: Jurnal Kesehatan Masyarakat, 7(1), 83-90.

Parwati, C. G., Farid, M. N., Nasution, H. S., Basri, C., Lolong, D., Gebhard, A., ... \& Houben, R. M. G. J. (2020). Estimation of subnational tuberculosis burden: generation and application of a new tool in Indonesia. The International Journal of Tuberculosis and Lung Disease, 24(2), 250-257.

Purba, Bahtera. (2017). "Efektifitas Pengawas Minum Obat Keluarga Sebagai Kontrol Penularan Tuberculosis Efektifitas Pengawas Minum Obat Keluarga Sebagai Kontrol Penularan Tuberculosis." Public Health Community 7(2): 43-49.

Purwanta, P. (2005). Ciri-Ciri Pengawas Minum Obat yang Diharapkan oleh Penderita Tuberkulosis Paru di Daerah Urban dan Rural di Yogyakarta. Jurnal Manajemen Pelayanan Kesehatan, 8(3). 141-47.

Putri, J. A. (2015). Hubungan Pengetahuan dan Tingkat Pendidikan PMO (Pengawas Minum Obat) Terhadap Kepatuhan Minum Obat Antituberkulosis Pasien TB Paru. Jurnal Majority, 4(8), 81-84.

Respati, T., \& Sufrie, A. (2014). Socio cultural factors in the treatment of pulmonary tuberculosis: a case of Pare-Pare municipality South Sulawesi. Global Medical \& Health Communication, 2(2), 60-65.

Risnawati, Indah. 2016. "Peran Keluarga Pada Kepatuhan Minum Obat Penderita Tb Di Kawedanan Pedan Klaten." Jurnal ARSI 3(1): 343-47.

Sharma, A. K., Gupta, N., Verma, S., Chandran, A., \& Dixit, R. (2019). A study on procedural delay in diagnosis and start of treatment in drug resistant tuberculosis under RNTCP. $\begin{array}{llll}\text { Indian Journal of } & \text { 3964-401. }\end{array}$ https://doi.org/10.1016/j.ijtb.2018.04.010.

Sitorus, B. (2016). "Pengobatan Penderita Tuberkulosa Diwilayah Kerja Unit Pengobatan Penyakit Paru-Paru ( Up4 ) PONTIANAK." Respirologi 3: 1-21.

Sitorus, B., Fatmawati, \& Rahmaniah, Syf. E. (2017). Peran Pengawas Menelan Obat(PMO) Terhadap Pengobatan Penderita Tuberkulosa Diwilayah Kerja Unit Pengobatan Penyakit Paru-Paru (UP4) Pontianak. Jurnal IImiah IImu Sosial dan IImu Politik Universitas Tanjungpura, 1-21.

Dhewi, G., Armiyati, Y., \& Supriyono, M. (2013). Hubungan Antara Pengetahuan, Sikap Pasien Dan Dukungan Keluarga Dengan Kepatuhan Minum Obat Pada Pasien. Journal of Chemical Information and Modeling, 53(9), 1689-1699.

Webb, E., Vanan, N. K., \& Biswas, R. (2018). Empirical treatment of tuberculosis: TB or not TB?. Case Reports, 2018: 2-5

World Health Organization. (2020). "'Tuberculosis', in Health at a Glance." Asia/Pacific 2020: Measuring Progress Towards Universal Health Coverage, OECD Publishing, Paris. 2018-20.

World Health Organization. (2020). Health at a Glance: Asia/Pacific 2020 MeasuringProgress Towards Universal Health Coverage: Measuring Progress Towards Universal Health Coverage. OECD Publishing.

Wulandari, D. H. (2018). Analisis Faktor-Faktor yang Berhubungan dengan Kepatuhan Pasien Tuberkulosis Paru Tahap Lanjutan Untuk Minum Obat di RS Rumah Sehat Terpadu Tahun 2015. Jurnal Administrasi Rumah Sakit Indonesia, 2(1): 17-28. 